\title{
Autosomal Recessive Oculodentodigital Dysplasia: A Case Report and Review of the Literature
}

\author{
Elifcan Taşdelen Ceren D. Durmaz Halil G. Karabulut
}

Department of Medical Genetics, Faculty of Medicine, Ankara University, Ankara, Turkey

\section{Established Facts}

- Oculodentodigital dysplasia (ODDD) is generally inherited as an autosomal dominant disorder, but in few cases recessive forms of the disease have been identified.

- Gap junction channels such as Cx43 play an essential role in the cardiomyocyte interconnection that provides synchronized cardiac contraction. Impairment in gap junction trafficking may result in cardiac complications such as arrhythmias and sudden cardiac death.

\section{Novel Insights}

- p.Arg148Ter, detected in our patient, is the third mutation described so far in the literature leading to the autosomal recessive form of the disease.

- A possible arrhythmia may have caused sudden death in our patient. Therefore, routine cardiac examination should be suggested for patients with ODDD.

\section{Keywords}

GJA1 - Oculodentodigital dysplasia - ODDD .

Microphthalmia · Syndactyly

\begin{abstract}
Oculodentodigital dysplasia (ODDD) is a rare condition characterized by a typical facial appearance and variable findings of the eyes, teeth, and fingers. ODDD is caused by mutations in the GJA1 gene in chromosome $6 \mathrm{q} 22$ and inherited in an autosomal dominant manner in the majority of the patients. However, in recent clinical reports, autosomal
\end{abstract}

recessive ODDD cases due to by GJA1 mutations were also described. Here, we report on a 14-year-old boy with microphthalmia, microcornea, narrow nasal bridge, hypoplastic alae nasi, prominent columnella, hypodontia, dental caries, and partial syndactyly of the 2nd and 3rd toes. These clinical findings were concordant with the diagnosis of ODDD, and a novel homozygous mutation (c.442C $>T$, p.Arg148Ter) was determined in the GJA1 gene leading to a premature stop codon. His phenotypically normal parents were found to be carriers of the same mutation. This is the third family in the literature in which ODDD segregates in an autosomal recessive manner.

(c) 2018 S. Karger AG, Basel

\section{KARGER}

(C) 2018 S. Karger AG, Basel

E-Mail karger@karger.com

www.karger.com/cgr
Elifcan Taşdelen

Ankara Üniversitesi Tip Fakültesi

Tıbbi Genetik AD, Dekanlık Binası

TR-06100 Ankara (Turkey)

E-Mail etasdelen@ ankara.edu.tr 
Oculodentodigital dysplasia (ODDD) is an inherited disorder with high penetrance and variable expressivity with involvement of the eyes, teeth, and limbs [Paznekas et al., 2003]. In addition to the autosomal dominant form of the disease, a recessive form was also defined recently (MIM 257850). In this form, besides ocular manifestations like microphthalmia, microcornea, iris abnormalities, and persistent pupillary membrane, hypoplastic alae nasi, long narrow nose, low-set ears, hypoplastic teeth, malocclusion, prominent upper incisors, delayed bone age, digital abnormalities, and sparse fine hair can also be seen. The digital malformations include syndactyly involving the 3rd, 4th, and 5th fingers and 2nd to 4th toes, camptodactyly, and clinodactyly due to absent phalanx of the toes. Abnormal gray and white matter differentiation in frontal, occipital, and cerebellar regions on CT scan and neurologic symptoms such as hypotonia at birth and psychomotor retardation were also described [Traboulsi et al., 1986; Pizzuti et al., 2004; Richardson et al., 2006]. Phenotypic features observed in both types of ODDD arise from mutations of the gap junction alpha 1 gene (GJA1; MIM 121014) located in chromosome 6q22. The gene has 2 exons separated by an 11-kb intron, and the complete coding region is included in the last exon [Paznekas et al., 2009]. GJA1 encodes the transmembrane protein connexin 43 (Cx43) [Willecke et al., 2002]. The human connexin family comprises 21 members of connexins [Laird, 2006]. Like all other connexin proteins, Cx43 consists of an intracellular $\mathrm{N}$-terminal region, 4 transmembrane regions, 2 extracellular loops, 1 cytoplasmic loop, and an intracellular C-terminal region [Skerrett and Williams, 2017]. Six connexins generate a connexon. A connexon of one cell lines up with a connexon of an opposing cell, building a gap junction that mediates the intercellular transport of ions and molecules up to $1 \mathrm{kDa}$ without exposure to the extracellular environment [Alexander and Goldberg, 2003; Esseltine and Laird, 2016].

Gap junction channels, such as $\mathrm{Cx} 43$, have principal roles in excitable tissues by easing rapid transport of action potentials between neighboring cells. Cardiac rhythm synchronization is organized by these ion channels at the cardiomyocyte cell-cell boundary. Impairment in gap junction trafficking leads to hazardous complications in the heart such as arrhythmias and sudden cardiac death [Epifantseva and Shaw, 2018].

Mutations in the GJA1 gene mostly result in an autosomal dominant pattern of ODDD [Paznekas et al., 2003]. In functional studies, most of these mutations were suggested to disrupt the gap junction assembly by a dominant negative effect leading to reduced channel function
[Flenniken et al., 2005]. On the other hand, recent reports have shown GJA1 mutations in 2 patients with ODDD (R76H and $\mathrm{R} 33 \mathrm{X}$ ) inherited in an autosomal recessive manner. In the current study, we present a 14-year-old boy with microphthalmia, microcornea, narrow nasal bridge, hypoplastic alae nasi, prominent columnella, hypodontia, dental caries, and partial syndactyly of the 2nd and $3 r$ does caused by a novel nonsense mutation in the GJA1 gene. Unfortunately, the patient suddenly died at the age of 15 .

\section{Case Report}

The proband was a 14-year-old male, the first child of consanguineous parents who had a second 6-year-old healthy son. He was born at term by cesarean section with a birth weight of $3,700 \mathrm{~g}$ (50-75th percentile) and a length of $52 \mathrm{~cm}$ (50-75th percentile). The perinatal history was uneventful, but he was noted to be macrocephalic and microphthalmic by 1 month of age. His psychomotor milestones were normal as he walked unaided at the age of 9 months. He was referred to our department because of his dysmorphic findings such as microphthalmia, microcornea, hypodontia, partial syndactyly of the 2 nd and 3 rd toes, and gait disturbance (Fig. 1a, b). His height was $171 \mathrm{~cm}$ (75-90th percentile), weight was $46 \mathrm{~kg}$ (25-50th percentile), and head circumference was $56 \mathrm{~cm}$ (75-90th percentile). His outer and inner canthal distance was $9 \mathrm{~cm}$ (50-75th percentile) and $4 \mathrm{~cm}(>2 \mathrm{SD})$, respectively, and midpupillary distance was $6 \mathrm{~cm}$ (75-97th percentile). His dysmorphic features were noted as flat face, wide forehead, bilateral epicanthus, microphthalmia, microcornea, hypertelorism, septal deviation, hypoplastic alae nasi, narrow nasal bridge, prominent columnella, high-arched palate, microdontia, hypodontia, misalignment of teeth, dental caries, low-set ears, pectus carinatum, flexion contracture of elbows, cubitus valgus, and partial syndactyly of the 2 nd and 3 rd toes. He had severe visual loss. MRI scan of the brain showed white matter alterations particularly in frontal, occipital and parietal regions as well as increased calvarium bone thickness. These findings were considered to result from myelination defects. Hearing tests were normal. The patient had no cardiac or renal complaints. EMG analysis which was performed due to gait disturbance was also normal. Despite the absence of cardiac complaints, the patient suddenly died at the age of 15 . His parents' and brother's general physical examinations were normal, and the family history was negative.

\section{Materials and Methods}

Genomic DNA was isolated from peripheral blood samples of the patient, his unaffected parents, and his brother using MagnaPure LC DNA Isolation Kit-Large Volume and MagnaPure LC instrument (Roche Applied Science, Mannheim, Germany). The GJA1 coding exon (exon 2) was amplified by PCR, and sequence analysis was performed using BigDye Terminator v3.1 Cycle Sequencing Kit on an ABI PRISM 3130 Genetic Analyzer (Thermo Fisher Scientific, Waltham, MA, USA).
182

Cytogenet Genome Res 2018;154:181-186 DOI: $10.1159 / 000489000$
Taşdelen/Durmaz/Karabulut 
Fig. 1. a Frontal appearance of the patient. Note microphthalmia and dysmorphic facial features. b Bilateral syndactyly of the 2nd and 3rd toes of the patient.
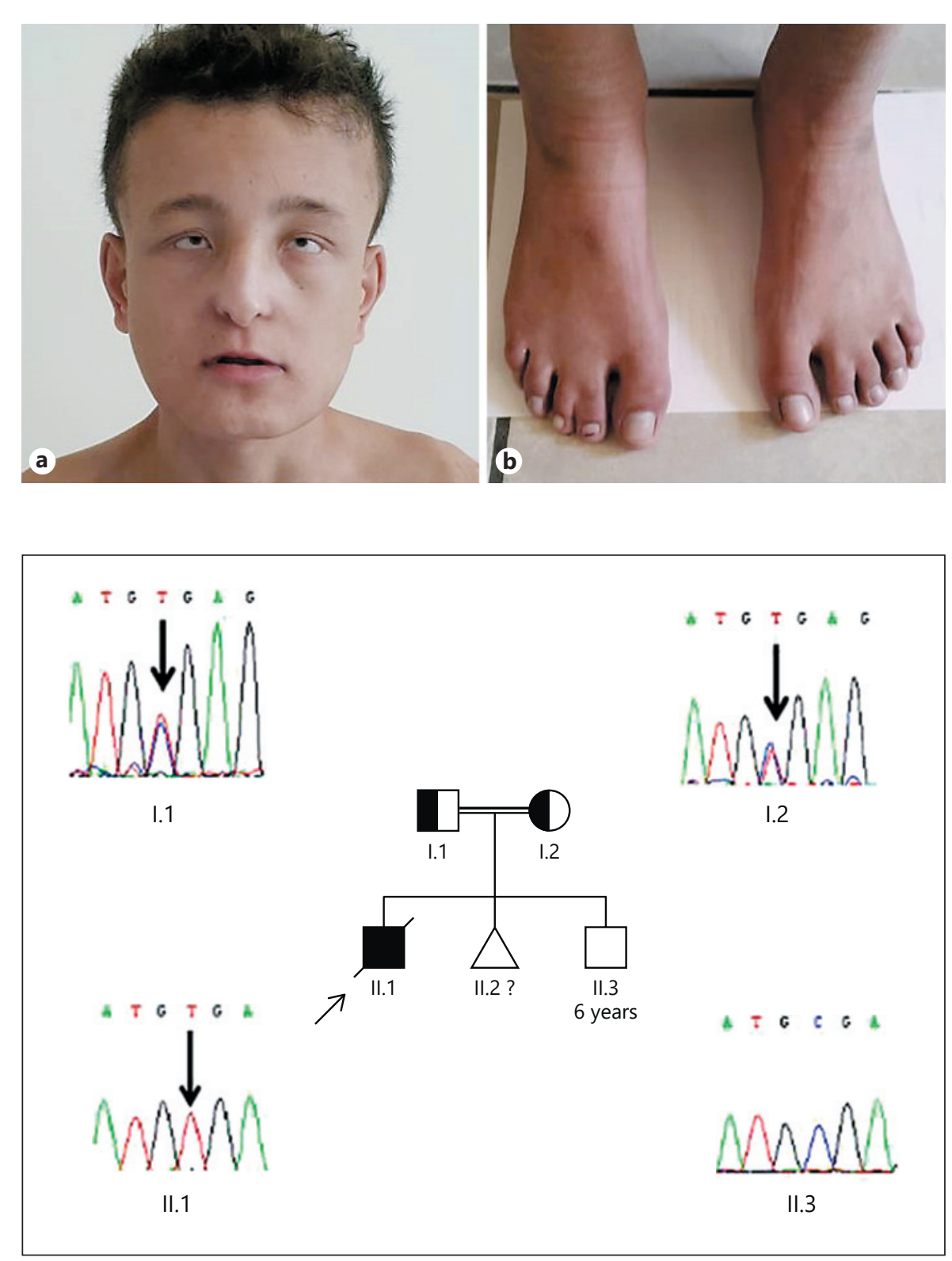

Fig. 2. Pedigree of the family and partial electropherograms of the individuals. The father (I.1) and mother (I.2) are heterozygous for the p.Arg148Ter mutation; the proband (II.1) is homozygous for the mutated allele (arrows). The proband's brother (II.3) is homozygous for the normal allele.

\section{Results}

We found a novel homozygous c.442C $>$ T, p.Arg148Ter mutation in the GJA1 gene of the patient. While his sibling had wild-type alleles, the mother and father were found to be heterozygous for the same mutation (Fig. 2). This variant was neither listed in the $1000 \mathrm{Ge}-$ nomes (http://browser.1000genomes.org/index.html) nor in the ExAC database (http://exac.broadinstitute. org/). The impact of the mutation on $\mathrm{Cx} 43$ structure and function predicted by in silico analysis was described as damaging.

Autosomal Recessive Oculodentodigital Dysplasia with a Novel Mutation

\section{Discussion}

Here, we present a case with recessively inherited ODDD and a novel homozygous nonsense mutation in the GJA1 gene that encodes the transmembrane protein Cx43. The vast majority of ODDD cases described in the literature show an autosomal dominant inheritance pattern and high phenotypic variability [Shapiro et al., 1997; Loddenkemper et al., 2002]. Up to date, 11 patients from 6 families with autosomal recessive ODDD have been reported [Gillespie, 1964; Beighton et al., 1979; Traboulsi et al., 1986; Frasson et al., 2004; Pizzuti et al., 2004; Richard- 
Table 1. Cases of autosomal recessive inheritance of ODDD and clinical findings of the patients

\begin{tabular}{|c|c|c|c|c|c|c|c|}
\hline & Gillespie, 1964 & $\begin{array}{l}\text { Beighton et al., } \\
1979\end{array}$ & $\begin{array}{l}\text { Traboulsi et al., } \\
1986\end{array}$ & Frasson et al., 2004 & Pizzuti et al., 2004 & Richardson et al., 2006 & Present case \\
\hline Number of patients & 2 (siblings) & 2 (1st cousins) & 1 & 3 (siblings) & 1 & 2 (siblings) & 1 \\
\hline Gender & $\mathrm{M} / \mathrm{F}$ & $\mathrm{M} / \mathrm{F}$ & $\mathrm{F}$ & $\mathrm{M} / \mathrm{M} / \mathrm{M}$ & M & $\mathrm{F} / \mathrm{F}$ & M \\
\hline Parental consanguinity & no & $\begin{array}{l}\text { no (isolated } \\
\text { ethnic group) }\end{array}$ & yes & yes & no & yes & yes \\
\hline Short stature & NC & $\mathrm{NC}$ & NC & $\mathrm{NC}$ & + & $+1-$ & - \\
\hline Microphthalmia & $+/+$ & $+/+$ & + & $+/+/+$ & - & $+/+$ & + \\
\hline Ocular examinations & NC & cataract & $\begin{array}{l}\text { PHPV and } \\
\text { dysplastic iris }\end{array}$ & PHPV and glaucoma & not done & PHPV & severe visual loss \\
\hline Fine hair & $+/+$ & $+/+$ & + & NC & + & $+/+$ & + \\
\hline Hypoplastic alae nasi & $+/+$ & $+/+$ & + & NC & + & $+/+$ & + \\
\hline Dental anomalies & $\begin{array}{l}\text { hypoplastic } \\
\text { enamel }+/-\end{array}$ & $\begin{array}{l}\text { hypoplastic } \\
\text { enamel }+/+\end{array}$ & $\begin{array}{l}\text { hypoplastic } \\
\text { enamel }+\end{array}$ & $\mathrm{NC} /$ enamel defects/NC & $\begin{array}{l}\text { hypoplastic enamel } \\
\text { and malocclusion }+\end{array}$ & $\begin{array}{l}\text { hypodontia / no teeth } \\
\text { at } 1 \text { year }\end{array}$ & $\begin{array}{l}\text { hypodontia and } \\
\text { microdontia }\end{array}$ \\
\hline Digital anomalies & $\begin{array}{l}\text { syndactyly of } \\
4 \text { th and } 5 \text { th } \\
\text { fingers } \\
+/-\end{array}$ & $\begin{array}{l}5 \text { th finger } \\
\text { clinodactyly } \\
+/-\end{array}$ & $\begin{array}{l}\text { syndactyly of } 4 \text { th } \\
\text { and } 5 \text { th fingers, } \\
\text { tissue syndactyly } \\
\text { of toes } 2,3,4\end{array}$ & $\begin{array}{l}\text { bilateral absence of the middle } \\
\text { phalanx, bilateral cutaneous } \\
\text { syndactyly of the } 2 \text { nd and } 3 \text { rd } \\
\text { toes / bilateral absence of the } \\
\text { middle phalanx of the } 2 \text { nd- } 5 \text { th } \\
\text { toes / bilateral cutaneous } \\
\text { syndactyly of the } 5 \text { toes, with } \\
\text { absence of the middle phalanx } \\
\text { of the } 2 \text { nd-5th toes }\end{array}$ & $\begin{array}{l}\text { bilateral } 5 \text { th finger } \\
\text { clinodactyly }\end{array}$ & $\begin{array}{l}\text { skin syndactyly of the } \\
\text { left ring and little } \\
\text { fingers and the right } \\
\text { middle, ring, and little } \\
\text { fingers / bilateral } \\
\text { syndactyly of her ring } \\
\text { and little fingers }\end{array}$ & $\begin{array}{l}\text { partial syndactyly } \\
\text { of } 2 \text { nd and } 3 \text { rd } \\
\text { toes }\end{array}$ \\
\hline Developmental state & NC & $\begin{array}{l}\text { normal IQ / } \\
\text { delayed walking }\end{array}$ & normal & $\begin{array}{l}\text { mild psychomotor retardation } \\
(1 / 3)\end{array}$ & $\begin{array}{l}\text { mild psychomotor } \\
\text { retardation }\end{array}$ & $\begin{array}{l}\text { psychomotor } \\
\text { retardation / normal }\end{array}$ & normal \\
\hline Brain imaging & not done & not done & $\begin{array}{l}\text { no basal ganglion } \\
\text { calcification }\end{array}$ & NC/IC /IC & not done & $\begin{array}{l}\text { poor myelination / } \\
\text { not done }\end{array}$ & $\begin{array}{l}\text { myelination } \\
\text { defects and white } \\
\text { matter } \\
\text { differentiation }\end{array}$ \\
\hline Other & $\begin{array}{l}\text { cleft lip and } \\
\text { palate }\end{array}$ & $\begin{array}{l}\text { mandibular } \\
\text { overgrowth }\end{array}$ & - & cardiomyopathy & - & $\begin{array}{l}\text { deceleration of head } \\
\text { growth }\end{array}$ & gait disturbance \\
\hline GJA1 mutation & not done & not done & not done & not done & $\begin{array}{l}\text { homozygous missense } \\
\text { R76H mutation }\end{array}$ & $\begin{array}{l}\text { homozygous nonsense } \\
\text { R33X mutation }\end{array}$ & $\begin{array}{l}\text { homozygous } \\
\text { nonsense } \\
\text { p.Arg148Ter } \\
\text { mutation }\end{array}$ \\
\hline Death & $-1-$ & $-/ 6$ years & - & 2 years/-I- & - & - & 15 years \\
\hline
\end{tabular}

son et al., 2006], but only 2 of these cases were confirmed by molecular analysis. Pizzuti et al. [2004] detected the $\mathrm{R} 76 \mathrm{H}$ homozygous missense variant in one of these patients, while Richardson et al. [2006] defined the R33X homozygous nonsense variant in the GJA1 gene in the second case. The p.Arg148Ter mutation identified in our patient is the third mutation reported so far in autosomal recessive ODDD cases. Clinical findings of the patients with autosomal recessive ODDD described in the literature and of the present case are summarized in Table 1.

As in autosomal dominant ODDD patients, phenotypic variability was also observed in the autosomal recessive form of the disease. Together with the classical findings including facial, dental, and limb defects, cardiac and neurological findings were also seen in some patients. For instance, there was cardiomyopathy in the cases described by Frasson et al. [2004]. Similar to our patient, a myelination defect was detected in the case of Richardson et al. [2006]. Psychomotor retardation was observed in only 3 of 11 cases with autosomal recessive ODDD described in the literature. Our patient's psychomotor development was normal. Similar to the digital anomalies in our patient, partial syndactyly of the 2nd and 3rd toes was present in the patients reported by Frasson et al. [2004] and Traboulsi et al. [1986].

In the literature, loss of the $\mathrm{Cx} 43$ protein was shown to be associated with sudden cardiac death. Studies demonstrated that mice with both cardiac-specific and global 
Fig. 3. Schematic presentation of the $\mathrm{Cx} 43$ protein with nonsense mutations (indicated by red lines) associated with the autosomal recessive form of ODDD. The $\mathrm{Cx} 43$ protein consists of 4 transmembrane domains, 2 extracellular loops, 1 intracellular (cytoplasmic) loop, and intracellular amino and carboxy termini. Cysteine residues are shown in purple and grey, respectively.

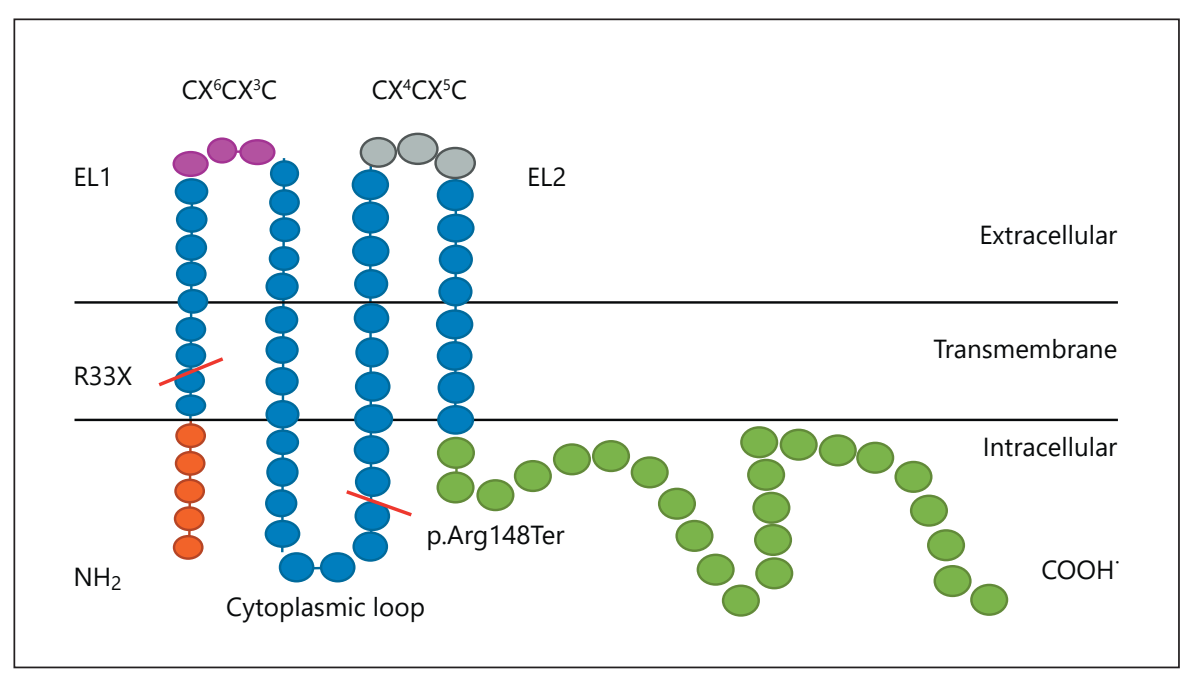

knockout of $\mathrm{Cx} 43$ exhibited structural cardiac anomalies, resulting in sudden death [Eckardt et al., 2006; Dobrowolski and Willecke, 2009]. Further, Thibodeau et al. [2010] found that isolated atrial fibrillation was associated with somatic $\mathrm{Cx} 43$ mutation in a patient. Unfortunately, we do not have more detailed information about a potential cardiac involvement in this condition as an autopsy was not done. However, in view of the above described studies, possible arrhythmia may have caused the sudden death in our patient and, therefore, cardiac screening should be considered for patients with ODDD diagnosis.

Most of the autosomal dominant ODDD cases described up to now have missense variants, and the disease occurs through 2 mechanisms: gain of function and dominant negative effect [Paznekas et al., 2003]. On the other hand, mutations found in patients with the recessive form of the disease resemble loss of function of the protein product, as expected. In a functional study on gap junctional intercellular communication-deficient HeLa cells, Huang et al. [2013] showed that while the R76H mutant protein trafficked to the plasma membrane to build gap junction-like plaques, the R33X mutant protein diffusely localized throughout the cell and failed to form functional channels. Although we did not perform functional studies, the homozygous nonsense mutation identified in our patient is also predicted to lead to a truncated nonfunctional protein. In the R33X mutation, the protein is truncated at the first transmembrane domain, whereas the first 2 transmembrane domains can be synthesized in the p.Arg148Ter mutation (Fig. 3). But, in our opinion, the p.Arg148Ter mutant protein can still fail to traffic to

Autosomal Recessive Oculodentodigital

Dysplasia with a Novel Mutation the cell surface and form functional channels due to the loss of the last 2 transmembrane domains. In addition, both extracellular loops include 3 cysteine residues that are highly conserved in the connexin family. The first extracellular loop (EL1) has a $\mathrm{CX}_{6} \mathrm{CX}_{3} \mathrm{C}$ motif, and the second extracellular loop (EL2) has $\mathrm{CX}_{4} \mathrm{CX}_{5} \mathrm{C}$. Extracellular cysteines are substantial for the formation of the connexon construction by the disulfide link between EL1 and EL2 [Warner et al., 1995]. In our opinion, connexon formation will probably be disrupted since the second extracellular loop will be lost in the presence of the p.Arg148Ter mutation. On the other hand, the mutation may also cause nonsense-mediated decay leading to complete loss of the protein. All these effects of the mutation on the protein product result in the loss of function, consistent with a recessive inheritance pattern. That the parents, heterozygous for the p.Arg148Ter mutation, have no phenotype of ODDD, suggests that the remaining Cx43 is sufficient for organ development and regulation, once again supporting autosomal recessive inheritance.

In summary, we identified a novel nonsense mutation in exon 2 of the GJA1 gene in a patient with ODDD syndrome. This nonsense mutation causes a premature stop codon and probably leads to nonfunctional protein which is responsible for the clinical features. This mutation is the third mutation described so far in the literature leading to the autosomal recessive form of the disease.

\section{Acknowledgements}

The authors would like to thank the patient and his family for their collaboration. 


\section{Statement of Ethics}

Informed consent was obtained from the patient and his family. The authors have no ethical conflicts to disclose.

\section{Disclosure Statement}

The authors have no conflicts of interest to declare.

\section{References}

-Alexander DB, Goldberg GS: Transfer of biologically important molecules between cells through gap junction channels. Curr Med Chem 10:2045-2058 (2003).

Beighton P, Hamersma H, Raad M: Oculodentoosseous dysplasia: heterogeneity or variable expression? Clin Genet 16:169-177 (1979).

Dobrowolski R, Willecke K: Connexin-caused genetic diseases and corresponding mouse models. Antioxid Redox Signal 11:283-296 (2009).

Eckardt D, Kirchhoff S, Kim JS, Degen J, Theis M, et al: Cardiomyocyte-restricted deletion of connexin43 during mouse development. J Mol Cell Cardiol 41:963-971 (2006).

-Epifantseva I, Shaw RM: Intracellular trafficking pathways of Cx43 gap junction channels. Biochim Biophys Acta 1860:40-47 (2018).

Esseltine JL, Laird DW: Next-generation connexin and pannexin cell biology. Trends Cell Bio 26:944-955 (2016)

-Flenniken AM, Osborne LR, Anderson N, Ciliberti N, Fleming C, et al: A Gjal missense mutation in a mouse model of oculodentodigital dysplasia. Development 132:4375-4386 (2005)

Frasson M, Calixto N, Cronemberger S, Aguiar RAL, Leão LL, Aguiar MJ: Oculodentodigital dysplasia: study of ophthalmological and clinical manifestations in three boys with probably autosomal recessive inheritance. Ophthalmic Genet 25:227-236 (2004).
Gillespie F: A hereditary syndrome: dysplasia oculodentodigitalis. Arch Ophthalmol 71:187192 (1964).

-Huang T, Shao Q, MacDonald A, Xin L, Lorentz $\mathrm{R}$, et al: Autosomal recessive GJA1 ( $\mathrm{Cx} 43)$ gene mutations cause oculodentodigital dysplasia by distinct mechanisms. J Cell Sci 126: 2857-2866 (2013).

Laird DW: Life cycle of connexins in health and disease. Biochem J 394:527-543 (2006).

Loddenkemper T, Grote K, Evers S, Oelerich M, Stögbauer F: Neurological manifestations of the oculodentodigital dysplasia syndrome. J Neurol 249:584-595 (2002).

- Paznekas WA, Boyadjiev SA, Shapiro RE, Daniels O, Wollnik B, et al: Connexin 43 (GJA1) mutations cause the pleiotropic phenotype of oculodentodigital dysplasia. Am J Hum Genet 72:408-418 (2003)

Paznekas WA, Karczeski B, Vermeer S, Lowry RB, Delatycki M, et al: GJA1 mutations, variants, and connexin 43 dysfunction as it relates to the oculodentodigital dysplasia phenotype. Hum Mutat 30:724-733 (2009).

Pizzuti A, Flex E, Mingarelli R, Salpietro C, Zelante L, Dallapiccola B: A homozygous GJA1 gene mutation causes a Hallermann-Streiff/ ODDD spectrum phenotype. Hum Mutat 23: 286-286 (2004).
Richardson R, Joss S, Tomkin S, Ahmed M, Sheridan E, Dixon M: A nonsense mutation in the first transmembrane domain of connexin 43 underlies autosomal recessive oculodentodigital syndrome. J Med Genet 43:e37 (2006).

Shapiro RE, Griffin JW, Stine OC: Evidence for genetic anticipation in the oculodentodigital syndrome. Am J Med Genet 71:36-41 (1997).

-Skerrett IM, Williams JB: A structural and functional comparison of gap junction channels composed of connexins and innexins. Dev Neurobiol 77:522-547 (2017)

Thibodeau IL, Xu J, Li Q, Liu G, Lam K, et al: Paradigm of genetic mosaicism and lone atrial fibrillation: physiological characterization of a connexin 43-deletion mutant identified from atrial tissue. Circulation 122:236-244 (2010).

Traboulsi EI, Faris BM, Kaloustian VMD, Opitz JM, Reynolds JF: Persistent hyperplastic primary vitreous and recessive oculo-dento-osseous dysplasia. Am J Med Genet 24:95-100 (1986).

Warner A, Clements D, Parikh S, Evans WH, DeHaan R: Specific motifs in the external loops of connexin proteins can determine gap junction formation between chick heart myocytes. J Physiol 488:721-728 (1995).

-Willecke K, Eiberger J, Degen J, Eckardt D, Romualdi A, et al: Structural and functional diversity of connexin genes in the mouse and human genome. Biol Chem 383:725-737 (2002). 